\title{
Rice Yield Estimation Using Landsat ETM+ Data and Field Observation
}

\author{
I Wayan Nuarsa (Corresponding author) \\ Faculty of Agriculture, Udayana University \\ Kampus Bukit Jimbaran 80361, Bali, Indonesia \\ Tel: 62-361-703-602 E-mail: nuarsa@ymail.com \\ Fumihiko Nishio \\ Center for Environmental Remote Sensing, Chiba University \\ 1-33 Yayoi-cho, Inage-ku, Chiba-shi 263-8522, Japan \\ Tel: 81-043-290-3836 E-mail: fnishio@faculty.chiba-u.jp \\ Chiharu Hongo \\ Center for Environmental Remote Sensing, Chiba University \\ 1-33 Yayoi-cho, Inage-ku, Chiba-shi 263-8522, Japan \\ Tel: 81-043-290-3859Ｅ-mail: hongo@faculty.chiba-u.jp
}

Received: July 11, 2011

Accepted: July 25, $2011 \quad$ Online Published: December 29, 2011

doi:10.5539/jas.v4n3p45

URL: http://dx.doi.org/10.5539/jas.v4n3p45

The research is financed by Japan Society for the Promotion of Science (JSPS) Ronpaku, Japan

\begin{abstract}
Forecasting rice yield before harvest time is important to supporting planners and decision makers to predict the amount of rice that should be imported or exported and to enable governments to put in place strategic contingency plans for the redistribution of food during times of famine. This study used the Normalized Difference Vegetation Index (NDVI) of Landsat Enhanced Thematic Mapper plus (ETM+) images of rice plants to estimate rice yield based on field observation. The result showed that the rice yield could be estimated using the exponential equation of $\mathrm{y}=0.3419 \mathrm{e}^{4.1587 \mathrm{x}}$, where $\mathrm{y}$ and $\mathrm{x}$ are rice yield and NDVI, respectively. The $\mathrm{R}^{2}$ and SE of the estimation were 0.852 and 0.077 ton/ha, respectively. An accuracy assessment of rice yield estimation using Landsat images was performed by comparing the rice yields from the estimation result and the reference data. The results show that the linear relationship with the $\mathrm{R}^{2}$ and SE of the estimation were 0.9262 and 0.21 ton/ha, respectively. The $\mathrm{R}^{2}$ is greater than or equal to 0.8 , which demonstrates a strong agreement between the remotely sensed estimation and the reference data. Thus, the Landsat ETM+ has good potential for application to rice yield estimation.
\end{abstract}

Keyword: Rice yield, Estimation, Landsat ETM+, Remote sensing

\section{Introduction}

Rice is one of the most important agriculture crops in many countries, and it is a primary food source for more than three billion people worldwide (Khush 2005, Yang et al. 2008). Forecasting crop yield well before harvest is crucial, especially in regions characterised by climatic uncertainties. Forecasting enables planners and decision makers to predict how much to import in the case of a shortfall or, optionally, to export in the case of a surplus. Forecasting also enables governments to put in place strategic contingency plans for the redistribution of food during times of famine. Therefore, the monitoring of crop development and crop growth and early yield prediction are generally of great importance (Sawasawa 2003, Huang et al. 2002). 
Crop yield estimation in many countries is based on conventional techniques of data collection for crop and yield estimation based on ground-based field visits and reports. Such reports are often subjective, costly, time-consuming and prone to large errors due to incomplete ground observation, leading to poor crop yield assessment and crop area estimations (Reynolds et al. 2000). In most countries, the data become available too late for the appropriate actions to be taken to avert food shortage (Sawasawa 2003, Nuarsa et al. 2005).

Satellite remote sensing has been widely applied and is recognised as a powerful and effective tool for identifying agriculture crops (Bouvet et al. 2009, Pan et al. 2010, Niel et al. 2003; Nuarsa et al. 2011). An important goal of agricultural remote sensing research is to spectrally estimate crop variables related to crop conditions, which can subsequently be entered into crop simulation and yield models (Ahlrichs \& Bauer 1983). To utilise the full potential of remote sensing for the assessment of crop conditions and yield prediction, it is essential to quantify the relationships between the agronomic parameters and spectral properties of the crop (Patel et al. 1985, Nuarsa \& Nishio 2007). Use of satellite spectral data for the estimation of crop yields is an attractive prospect because yield is related to crop vigour, which is related to the spectral response of the crop vigour, which in turn is related to the spectral response of the crop measured by satellite sensors (Barnett \& Thompson, 1982). There are reports of various studies on the suitability of satellite data for estimating crop yields. The correlation between the spectral reflectance of crops and agronomic variables has encouraged the application of these data in crop yield models (Tucker et al. 1980, Richardson et al. 1982).

Some of the research regarding the use of remote sensing in rice yield estimation uses global resolution images, such as those from the National Oceanic and Atmospheric Administration Advanced Very High Resolution Radiometer (NOAA AVHRR), to monitor rice fields (Quarmby et al. 1993, Rasmussen 1997, Huang et al. 2002). However, the use of the global spatial resolution of satellite imaging has been restricted, particularly in small rice areas, because many types of land cover can appear in one pixel, which reduces the accuracy of the assessment (Strahler et al. 2006). In contrast, the utilisation of fine or medium spatial resolution satellite images, especially in session plants, has been limited because fewer images are available during the 120-day rice growth period (Currey et al. 1987). Landsat ETM+ has a good temporal, spatial, and spectral resolution for rice monitoring. The revisit time of Landsat ETM+ is 16 days, with a spatial resolution of $30 \mathrm{~m}$. Landsat ETM+ has six bands with the same pixel size, and it has become beneficial in the development of algorithms for rice yield modelling (Christopher 2004).

The objectives of this study include the following: (1) to determine the best rice age for the relationship between rice growth parameters and rice yield; (2) to develop a model for rice yield estimation based on Landsat spectral images (NDVI); and (3) to assess the accuracy of the rice yield estimation model.

\section{Study Area, Data and Method}

\subsection{Background and study area}

The study area was located in Tabanan Regency, Bali Province, Indonesia, at $8^{\circ} 31^{\prime} 50^{\prime \prime} \mathrm{S}$ latitude and $115^{\circ} 02^{\prime} 30^{\prime \prime}$ E longitude (Figure 1). The Tabanan Regency was selected as the study area because Tabanan is the central area for rice production in Bali. Within the study area, rice plantings are organised by a Subak, which is a social organisation centred around farming. The Subak manages irrigation water for approximately $150-300$ ha of rice fields (Food Crops Agriculture Department 2006). Moreover, rice fields managed by the Subak are often planted at the same time. Due to the wide rice area, this type of farming system can be easily monitored by remote sensing.

\subsection{Field observation}

The field observation was conducted at eight stations from the middle of January 2011 to the middle of April 2011. The geographic coordinates of the field observations are shown in Table 1. The parameters measured in the field observation consist of transplanting date, rice variety, inter-row space, inter-plant distance, fertilisers and pesticides used, rice height, level of rice leaf greenness, and rice yield. The rice height and rice leaf greenness were measured using a ruler and the Minolta SPAD-502 leaf chlorophyll meter, respectively. The rice yield sample was performed in area of $2.5 \mathrm{~m}$ by $2.5 \mathrm{~m}$ in units of $\mathrm{kg}$. The rice production was then converted into units of ton/ha. The measurement of rice height and the level of rice leaf greenness was performed from rice transplanting until harvest.

\subsection{Collection of secondary data for rice grain sample}

In addition to collecting rice yield from our field observation, we also collected rice yield from the secondary data (BPS 2009, BPS 2010). These data were used to develop an algorithm for rice yield estimation with satellite images (Landsat images). The following considerations were used to select the rice grain sampling sites: (1) the 
planted area should be wide and easily identifiable in Landsat images; (2) the planted area should have the same rice variety; (3) the age of the rice plant exhibits the best relationship between rice growth and rice yield according to the field observation survey. A total of 26 rice yield samples were collected in this study in 2008 and 2009 (Table 2).

\subsection{Landsat images}

Landsat ETM+ acquired in 2008 and 2009 were used in this study. This satellite image can be freely downloaded from the NASA website (http://glovis.usgs.gov). The Landsat in 2009 was used to develop the model for rice yield estimation, and the Landsat in 2008 was utilised to assess the accuracy of the model. The total of the Landsat images used in this study are 8 scenes for both 2008 and 2009 (Table 3).

\subsection{Data analysis}

There are three steps to the data analysis in this study: analysis of the field observations, digital image processing of Landsat ETM+, and an accuracy assessment of the analysis results.

\subsubsection{Data analysis of the field observation}

A data analysis of the field observations was performed to determine the relationship between the rice growth parameters and rice yield. The rice height, rice leaf greenness, and their combinations are the main aspects of rice growth evaluated in this study. These parameters can be monitored from the satellite images using a vegetation index. A question arises when the best relationship occurs between rice parameters and rice yield. To address this question, we calculated the relationship between rice height, rice leaf greenness, and rice height times leaf greenness with rice yield at every 7 days of rice age. The highest coefficient of determination $\left(R^{2}\right)$ and the lowest standard error of estimation (SE) were judged as the best relationship. The $\mathrm{R}^{2}$ and SE were calculated using the following equation.

$$
\begin{gathered}
\mathrm{R}^{2}=1-\frac{\left.\sum \mathrm{y}-\overline{\mathrm{y}}^{\prime}\right)^{2}}{\left.\sum \mathrm{y}-\mathrm{y}^{\prime}\right)^{2}} \\
\mathrm{SE}=\sqrt{\frac{\sum\left(\mathrm{y}-\mathrm{y}^{\prime}\right)^{2}}{\mathrm{n}}}
\end{gathered}
$$

where $\mathrm{R}^{2}, \mathrm{SE}, \mathrm{y}, \mathrm{y}^{\prime}, \overline{\mathrm{y}}^{\prime}$, and $\mathrm{n}$ are the determination coefficient, standard error of estimation, actual value, predicted value, average predicted value, and number of samples, respectively.

\subsubsection{Landsat image processing}

The first step of Landsat image processing was radiometric correction. The digital number (DN) of the Landsat ETM + at different acquisition dates was converted to the corrected digital number (cDN) to eliminate the radiometric and atmospheric effects of the images so that they had comparable values. In this study, we used a simple radiometric correction model introduced by Pons \& Solé-Sugrañes (1994). The variables used for the radiometric correction are shown in Tables 3 and 4 . The form of the model is as follows:

$$
c D N=1000 a\left(D N-K_{l}\right) d^{2} /\left[\mu_{S} S_{0} e^{\left(-\tau_{0} / \mu_{0}\right)} e^{\left(-\tau_{0} / \mu_{v}\right)}\right]
$$

(i) (if $250<\mathrm{cDN} \leq 318.3 ; \mathrm{cDN}=254$ ),

(ii) (if $\mathrm{cDN}>318.3 ; \mathrm{cDN}=255$ ),

(iii) (if $\mu_{\mathrm{s}} \leq 0$; $\mathrm{cDN}=255$ ),

where $\quad \mathrm{cDN}=$ corrected digital number

$\mathrm{a}=$ gain value of each Landsat band

$\mathrm{DN}=$ digital number

$\mathrm{K}_{1}=$ radiance value of zone completely under shade

$\mathrm{d}=$ actual Sun-Earth distance

$\mu_{\mathrm{s}}=$ cosine of the incident angle

$\mathrm{S}_{0}=$ exoatmospheric solar irradiance

$\tau_{0}=$ optical depth of the atmosphere 
$\mu_{0}=$ cosine of the solar zenith angle

$\mu_{\mathrm{v}}=$ cosine of the sensor view angle

A Landsat spectral was obtained for the location of the rice grain sampling (Table 2). The Normalized Vegetation Index (NDVI) was then calculated according to the following expression:

$$
N D V I=\frac{\text { Infrared band }- \text { Red } \text { band }}{\text { Infrared band }+ \text { Red band }}
$$

The red and infrared bands of the NDVI equation were band-3 and band- 4 of Landsat respectively, which were radiometrically corrected. The next step is to determine the relationship between NDVI and rice yield with the equation below:

$$
y=f(x)
$$

where $\mathrm{y}$ and $\mathrm{x}$ are rice yield and NDVI, respectively. To develop the rice yield estimation model, we used the data of rice yield and Landsat images for 2009 .

\subsubsection{Accuracy assessment}

An accuracy assessment was performed to determine the accuracy of the rice yield estimation obtained from the analysis of the Landsat images. The value resulting from the estimated equation (Equation 5) compared with the reference rice yield was obtained from a statistical agency (BPS, 2009). Both the rice yield from the estimated result and the reference data were plotted on the chart to determine the level of agreement between the estimated result and the reference data. Schematically, the research procedure is shown in following flowchart.

\section{Result and Discussion}

\subsection{Relationship between rice growth parameters and rice yield based on field observations}

There were three parameters of rice growth evaluated in this study: rice plant height, leaf greenness, and plant height times leaf greenness. Tables 5-7 show the field measurement of the third rice growth parameters starting from a rice age of 28 days due to the unmeasured leaf greenness in the early rice age. The trend of rice height increased from the transplanting date to the age of 77 days, and it decreased until harvest time. Similar to rice height, the greenness of the rice leaves also increased from 28 days to 56 days after transplanting and decreased until the harvesting period. For rice height times leaf greenness, the peak value mostly occurred at a rice age of 63 days.

Based on the statistical analysis, the rice plants at 63 days after transplanting showed the best relationship between rice growth parameters and rice yield. From the three parameters evaluated in this study, the rice plant height times leaf greenness provided the highest coefficient of determination $\left(\mathrm{R}^{2}\right)$ and lowest standard error (SE). The $\mathrm{R}^{2}$ and SE values were 0.9598 and 0.139 , respectively, whereas the $\mathrm{R}^{2}$ and $\mathrm{SE}$ for rice height and rice leaf greenness individually were 0.8897 and 0.225 and 0.7171 and 0.364 , respectively (Figures 3-5).

The height of rice plants indicates the volume of biomass, and rice leaf greenness expresses the chlorophyll content of the rice plant. The multiplication of rice height by leaf greenness illustrates the total chlorophyll content of the biomass of rice. Chlorophyll is the most important component of the rice plant for photosynthetic activity, which produces carbohydrates to form rice plant tissue and the rice grain, and it has a significant effect on the rice yield at harvesting time. Therefore, the chlorophyll content of the biomass has a close relationship with rice yield.

The highest relationship of all rice growth parameters evaluated in this study with rice yield was found at an age of 63 days. This stage of rice growth represents the peak of its vegetation index and the highest chlorophyll content in its life. This period is also a transition stage of vegetation and generation (Nuarsa \& Nishio 2007).

\subsection{Relationship between vegetation index of Landsat images and rice yield}

Based on the field observation results, the best rice age for estimating rice yield from rice growth parameters is two months after transplanting. Therefore, an estimation of rice yield using remote sensing data (Landsat ETM + ) was performed at that rice age. Landsat ETM+ and location rice grain samples were selected for a rice age of two months. After radiometric correction to the Landsat ETM+ images, the digital values of the rice field in Landsat image were collected, and vegetation index (NDVI) was calculated using equation 4. From the 14 samples selected in the study (Table 8), there was an exponential relationship between NDVI and rice yield, with the equation $\mathrm{y}=0.3419 \mathrm{e}^{4.1587 \mathrm{x}}$ and an $\mathrm{R}^{2}=0.852$ (Figure 6), where $\mathrm{y}$ and $\mathrm{x}$ are the rice yield and NDVI, respectively. 
The exponential relationship between the NDVI and rice yield indicates that increasing NDVI values at approximately two months will increase the rice yield. Increasing NDVI significantly improves the rice yield at an NDVI value between 0.6 and 0.75 . However, above 0.75 , any increase in the NDVI value produces only a slight improvement in the rice yield.

The NDVI formula is formed by the red (B3) and near-infrared (B4) bands of Landsat ETM+. The NDVI value is directly proportional to the value of the near-infrared band and is inversely proportional to the value of the red band (Equation 4). An increase of the B3 value will decrease the NDVI value, and an increase of the B4 value will increase the NDVI value. Chlorophyll pigments present in the leaves absorb the red band. The near-infrared reflectance of rice is directly related to green biomass (Casanova et al. 1998). In the near-infrared portion, the radiation is scattered by the internal spongy mesophyll leaf structure, which leads to higher values in the near infrared (NIR) channels (Baret \& Guyot 1991; Harrison \& Jupp 1989). Thus, high NDVI values are indicative of high chlorophyll content. Chlorophyll is the most important component of the rice plant for photosynthetic activity to produce rice plant tissues and the rice grain.

\subsection{Accuracy assessment of rice yield estimation}

To determine the accuracy of the rice yield estimation based on the spectral value of Landsat images (NDVI), an accuracy assessment was performed. The collection procedure of the Landsat images and the rice yield sample was the same as with the development of the rice yield estimation model. The Landsat images used in this method were from 2008. The Landsat spectral values (B3, B4, and NDVI), rice yield from the reference, and rice yield resulting from the estimation equation are shown in Table 9. Based on the statistical analysis, there was a linear relationship between the referenced rice yields and the estimated rice yield with the equation $\mathrm{y}=0.7781 \mathrm{x}$ +1.1441 . The $\mathrm{R}^{2}$ and standard error of the estimation were 0.9262 and 0.21 ton/ha, respectively (Figure 7). The coefficient of determination greater than or equal to 0.8 demonstrates the strong agreement between the remotely sensed estimation and the reference data (Lillesand \& Kiefer 2000, Congalton et al. 1983).

\section{Conclusions}

The multiplication of rice height by rice leaf greenness at an age of 63 days showed the best relationship with rice yield based on the field observation. The form of this relationship was quadratic, with the equation of $y=$ $-8 \mathrm{E}-07 \mathrm{x}^{2}+0.0067 \mathrm{x}-7.1567$, and the $\mathrm{R}^{2}$ and SE of the estimation were 0.9589 and 0.139 , respectively. The estimation of rice yield using the vegetation index (NDVI) of Landsat ETM+ images produced an exponential relationship with the equation $\mathrm{y}=0.3419 \mathrm{e}^{4.1587 \mathrm{x}}$, where $\mathrm{y}$ and $\mathrm{x}$ are rice yield and NDVI, respectively. The $\mathrm{R}^{2}$ and SE of the estimation were 0.852 and 0.077 , respectively. An accuracy assessment of rice yield estimation using Landsat images was performed by comparing the rice yield resulting from the estimation result and the reference data. The result showed a linear relationship with the equation $\mathrm{y}=0.7781 \mathrm{x}+1.1441$, where $\mathrm{y}$ and $\mathrm{x}$ were rice yield from the estimate result and reference data, respectively, with the $\mathrm{R}^{2}$ and $\mathrm{SE}$ of the estimation at 0.9262 and 0.21 , respectively. The $\mathrm{R}^{2}$ greater than or equal to 0.8 demonstrates a strong agreement between the remotely sensed estimation and the reference data. Thus, Landsat ETM+ has a good potential for application to rice yield estimation.

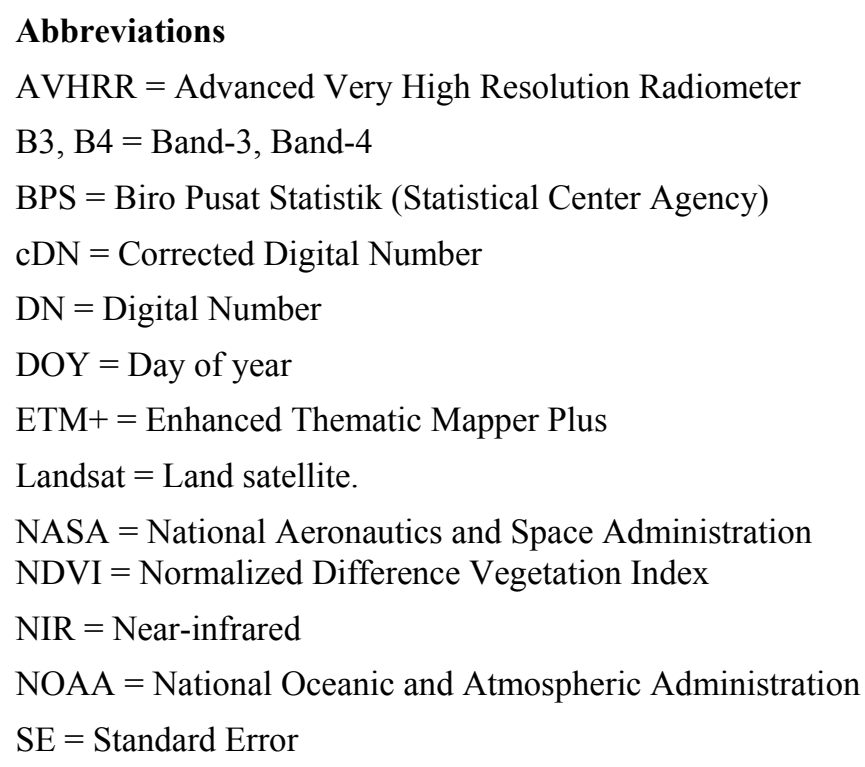




\section{Acknowledgments}

I would like to express my profound gratitude to my advisor for his invaluable support, encouragement, supervision, and useful suggestions throughout this research. I am also thankful to JSPS Ronpaku for supporting this PhD work.

\section{References}

Ahlrichs. J. S. \& Bauer, M.E. (1983). Relation of agronomic and multispectral reflectance characteristics of spring wheat canopies. Agronomy Journal, 75, 987 - 993.

Baret, F. \& Guyot, G. (1991). Potentials and limits of vegetation indices for LAI and APAR assessment. Remote Sensing of Environment, 35, 161-173.

Barnett, T. L. \& Thompson, D. R. (1982). The use of large-area spectral data in wheat yield estimation. Remote Sensing of Environment, 12, 509-518.

BPS. (2009). Report of Monthly Rainfall of Bali Province, Indonesia. Meteorological and Geophysical Agency, 2, 45-50.

BPS. (2010). Report of Monthly Rainfall of Bali Province, Indonesia. Meteorological and Geophysical Agency, 2, 51-56.

Bouvet, A., Le Toan, T. \&Lam-Dao, N. (2009). Monitoring of the Rice Cropping System in the Mekong Delta Using ENVISAT/ASAR Dual Polarization Data. IEEE Trans. Geoscience and Remote Sensing, 47, pp. 517 526.

Casanova, D., Epema, G.F. \& Goudriaan, J. (1998). Monitoring rice reflectance at field level for estimating biomass and LAI. Field Crops Research, 55, 83-92.

Chander, G., Markham, B.L., Dennis L. \& Helder, D.L. (2009). Summary of current radiometric calibration coefficients for Landsat MSS, TM, ETM+, and EO-1 ALI sensors. Remote Sensing of Environment, 113, 893-903.

Christopher Small. (2004). The Landsat ETM+ spectral mixing space. Journal of Remote Sensing of Environment, 93, 1-17.

Congalton, R.G. \& Green, K. (1999). Assessing the Accuracy of Remotely Sensed Data: Principles and Practices, 43-70 (Florida: Lewis Publishers).

Congalton, R.G., Oderwald, R.G. \& Mead, R.A. (1983). Assessing Landsat Classification Accuracy Using Discrete Multivariate Analysis Statistical Techniques. PERS, 49, 1671-1678.

Currey, B., Fraser, A. S. \& Bardsley, K. L. (1987). How useful is Landsat monitoring. Nature, 328, 587-590.

Dozier, J. (1989). Spectral signature of Alpine snow cover from the Landsat Thematic Mapper. Remote Sensing of Environment, 28, 9-22.

Food Crops Agriculture Department. (2006). Annual report of food crops, 125-135. (Department Agriculture of Local Government).

Harrison, B. A. \& Jupp, D. L. B. (1989). Introduction to remotely sensed data, 1, 65. (CSIRO Publications).

Huang, J.F, Tang, S.C., Ousama A.I. \& Wang R.C. (2002). Rice yield estimation using remote sensing and simulation. Journal of Zhejiang University Science, 3, 461 - 466.

Khush, G.S. (2005). What it will take to feed 5 billion rice consumers in 2030. International Journal of Molecular Biology, 59, 1-6.

Lillesand, T. M. and Kiefer, R. W. (2000). Remote sensing and image interpretation, 715-735 (New York: Wiley \& Son).

Niel, T.G.V. \& McVicar, T.R. (2003). A Simple method to improve field-level rice identification: toward operational monitoring with satellite remote sensing. Australian Journal of Experimental Agriculture, 43, 379-387.

Nuarsa I.W., Kanno, S., Sugimori, Y. \& Nishio, F. (2005). Spectral Characterization of Rice Field Using Multi-Temporal Landsat ETM+ Data. International Journal of Remote Sensing and Earth Sciences, 2, 65-71.

Nuarsa, I.W. \& Nishio, F. (2007). Relationships between Rice Growth Parameters and Remote Sensing Data. International Journal of Remote Sensing and Earth Sciences, 4, 102-112. 
Nuarsa, I.W., Nishio, F. \& Hongo, C. (2011). Spectral Characteristics and Mapping of Rice Plants Using Multi-Temporal Landsat Data. Journal of Agriculture Science, 3, 54-67.

Pan, X.Z., Uchida, S., Liang, Y., Hirano, A. \& Sun, B. (2010). Discriminating different landuse types by using multitemporal NDXI in a rice planting area. International Journal of Remote Sensing, 31, 585-596.

Patel, N. K., Singh, T. P., Sahai, B. \& Patel, M. S. (1985). Spectral response of rice crop and its relation to yield and yield attributes. International Journal of Remote Sensing, 6, 657 - 664.

Pons, X. \& Solé-Sugrañes, L. (1994). A simple radiometric correction model to improve automatic mapping of vegetation from multispectral satellite data. Remote Sensing of Environment, 48, 191-204.

Quarmby, N. A., Milnes, M., Hindle, T. L. \& Silleos, N. (1993). The use of multi-temporal NDVI measurements from AVHRR data for crop yield estimation and prediction. International Journal of Remote Sensing, 14, 199-210.

Rasmussen, M. S. (1997). Operational yield forecast using AVHRR NDVI data: reduction of environmental and inter-annual variability. International Journal of Remote Sensing, 18, 1059-1077.

Reynolds, C.A., Yitayew, M., Slack, D.C. Hutchison, C.F., Huete, A., \& Petersen, M.S. (2000). Estimating crop yields and production by integrating the FAo crop specific water balance model with real-time satellite data and ground based ancilliary data. International Journal of Remote Sensing, 21, 3487-3508.

Richardson, A. J., Wiegand, C. L., Arkin, G. F., Nixon, P. R. \& Gerbermann, A . H. (1982). Remotely-sensed spectral indicators of sorghum development and their use in growth. Agricultural Meteorology, 26, 11-23.

Sawasawa, Haig L.S. (2003). Crop Yield Estimation: Integrating RS, GIS, and Management Factor. A case study of Birkoor and Kortigiri Mandals, Nizamabad District India. Available on http://www.itc.nl/library/papers_2003/msc/nrm/sawasawa.pdf, 1-9 (April 10, 2011)

Strahler, A. H., Boschetti, L., Foody, G.M., Friedl, M.A., Hansen, M.C., Herold, M., Mayaux, P., Morisette, J.T., Stehman, S.V. \& Woodcock, C.E. (2006). Global Land Cover Validation: Recommendations for Evaluation and Accuracy Assessment of Global Land Cover Maps. Office for Official Publications of the European Communities. Available:

Validation_JeffMorisette.pdf (July 25, 2009.)

Tucker, C. J., Holben, B. N., Elgin, J. H. Jr., Mc- Murtrey. (1980). Remote sensing of dry matter accumulation in winter wheat. Remote Sensing of Environment, 11, 171-189.

Yang, C.M., Liu, C.C. and Wang, Y.W. (2008). Using Formosat-2 Satellite Data to Estimate Leaf Area Index of Rice Crop. Journal of Photogrammetry and Remote Sensing, 13, 253-260.

Table 1. Location coordinates, transplanting date, and harvesting date of the field observations

\begin{tabular}{|c|l|c|c|c|c|}
\hline \multirow{2}{*}{ No } & \multirow{2}{*}{ Subak Name } & \multicolumn{2}{|c|}{ Geographic coordinate } & \multirow{2}{*}{ Transplanting date } & \multirow{2}{*}{ Harvesting date } \\
\cline { 3 - 4 } & & $\mathrm{X}$ & $\mathrm{Y}$ & & \\
\hline 1 & Gadon & 291319 & 9048755 & 29-Nov-2010 & 27-Feb-2011 \\
\hline 2 & Gadon & 291331 & 9048755 & 1-Dec-2010 & 7-Mar-2011 \\
\hline 3 & Medah 4 & 290738 & 9049284 & 3-Jan-2011 & 10-Apr-2011 \\
\hline 4 & Medah 4 & 290762 & 9049318 & 10-Dec-2010 & 21-Mar-2011 \\
\hline 5 & Medah 4 & 290200 & 9049257 & 14-Dec-2010 & 27-Mar-2011 \\
\hline 6 & Bengkel & 290032 & 9049858 & 2-Dec-2010 & 7-Mar-2011 \\
\hline 7 & Bengkel & 290113 & 9050166 & 25-Nov-2010 & 27-Feb-2011 \\
\hline 8 & Bengkel & 289729 & 9050388 & 4-Dec-2010 & 27-Feb-2011 \\
\hline
\end{tabular}


Table 2. Location coordinates, transplanting date, harvesting date, and rice yield of the secondary data

\begin{tabular}{|l|l|l|c|c|c|c|}
\hline \multirow{2}{*}{ No } & \multirow{2}{*}{ Village Name } & \multicolumn{2}{|c|}{ Geographic coordinate } & Transplanting & Harvesting & Yield \\
\cline { 3 - 7 } & & \multicolumn{1}{|c|}{$\mathrm{X}$} & $\mathrm{Y}$ & Date & Date & Ton/ha \\
\hline 1 & Nyambu & 296565 & 9051325 & 17-Aug-2009 & 19-Nov-2009 & 5.696 \\
\hline 2 & Mengeste & 294765 & 9070165 & 22-Aug-2009 & 21-Nov-2009 & 6.512 \\
\hline 3 & Wangaya Gede & 291555 & 9071665 & 16-Aug-2009 & 20-Nov-2009 & 5.136 \\
\hline 4 & Kuwum & 297705 & 9061855 & 18-Aug-2009 & 19-Nov-2009 & 6.368 \\
\hline 5 & Mekar Sari & 300735 & 9074155 & 18-Aug-2009 & 24-Nov-2009 & 3.584 \\
\hline 6 & Belalang & 289245 & 9047545 & 4-Aug-2009 & 6-Nov-2009 & 6.912 \\
\hline 7 & Wanagiri & 286035 & 9070975 & 11-Mar-2009 & 9-Jun-2009 & 5.152 \\
\hline 8 & Tunjuk & 296775 & 9061225 & 12-Mar-2009 & 16-Jun-2009 & 5.504 \\
\hline 9 & Perean Kangin & 303015 & 9067285 & 14-Mar-2009 & 15-Jun-2009 & 6.128 \\
\hline 10 & Tengkudak & 293805 & 9068935 & 10-Mar-2009 & 8-Jun-2009 & 7.648 \\
\hline 11 & Wangaya Gede & 290835 & 9070015 & 12-Mar-2009 & 13-Jun-2009 & 5.920 \\
\hline 12 & Tajem & 295815 & 9064945 & 6-Feb-2009 & 10-May-2009 & 7.488 \\
\hline 13 & Kuwum & 297705 & 9061555 & 22-Jan-2009 & 25-Apr-2009 & 5.152 \\
\hline 14 & Denbantas & 295245 & 9058825 & 24-Jan-2009 & 26-Apr-2009 & 6.160 \\
\hline 15 & Denbantas & 294495 & 9058435 & 24-Jan-2008 & 23-Apr-2008 & 6.448 \\
\hline 16 & KukuhMarga & 297255 & 9057745 & 18-Jan-2008 & 25-Apr-2008 & 6.896 \\
\hline 17 & Perean Kangin & 302685 & 9069085 & 21-Jan-2008 & 23-Apr-2008 & 6.704 \\
\hline 18 & Biaung & 297615 & 9069685 & 21-Jan-2008 & 20-Apr-2008 & 5.968 \\
\hline 19 & Pupuan Sawah & 284985 & 9064735 & 28-Mar-2008 & 26-Jun-2008 & 5.344 \\
\hline 20 & Angseri & 298185 & 9075355 & 27-Mar-2008 & 3-Jul-2008 & 5.456 \\
\hline 21 & Apuan & 299175 & 9075445 & 22-Mar-2008 & 24-Jun-2008 & 7.024 \\
\hline 22 & Bangli & 299205 & 9077215 & 24-Mar-2008 & 20-Jun-2008 & 6.064 \\
\hline 23 & Buruan & 294555 & 9064495 & 25-Mar-2008 & 24-Jun-2008 & 6.736 \\
\hline 24 & Tengkudak & 292455 & 9070405 & 22-Mar-2008 & 26-Jun-2008 & 7.328 \\
\hline 25 & Biaung & 298035 & 9069415 & 25-Mar-2008 & 25-Jun-2008 & 6.928 \\
\hline 26 & Senganan & 295605 & 9073825 & 23-Mar-2008 & 26-Jun-2008 & 7.731 \\
\hline
\end{tabular}

Table 3. Values of $\mathrm{d}(1), \mu_{0}(2)$, and $\mathrm{K}_{\mathrm{l}}(3)$ for every acquisition date of Landsat ETM+ in healthy rice

\begin{tabular}{|c|c|c|c|c|c|c|c|c|c|c|c|}
\hline \multirow{2}{*}{ Acquisition date } & \multirow{2}{*}{ Path } & \multirow{2}{*}{ Row } & \multirow{2}{*}{ DOY } & \multirow{2}{*}{$\mathrm{d}$} & \multirow{2}{*}{$\mu_{0}$} & \multicolumn{6}{|c|}{$\mathrm{K}_{1}$} \\
\cline { 8 - 13 } & & & & & & & & & \multicolumn{6}{|c|}{} \\
\hline 18-Mar-2008 & 116 & 66 & 96 & 1.00069 & 0.822732 & 45.77 & 27.02 & 14.81 & 25.80 & 2.02 & 0.31 \\
\hline 21-May-2008 & 116 & 66 & 128 & 1.00928 & 0.776037 & 45.00 & 26.22 & 14.81 & 23.86 & 1.89 & 0.35 \\
\hline 6-Apr-2009 & 116 & 66 & 288 & 0.99718 & 0.892566 & 54.30 & 36.57 & 21.01 & 34.49 & 3.27 & 0.57 \\
\hline 8-May-2009 & 116 & 66 & 80 & 0.99612 & 0.833491 & 42.67 & 24.63 & 11.72 & 20.00 & 1.39 & 0.22 \\
\hline 15-Oct-2009 & 116 & 66 & 112 & 1.00519 & 0.802622 & 47.32 & 28.61 & 14.81 & 23.86 & 1.89 & 0.31 \\
\hline 21-Mar-2009 & 116 & 66 & 272 & 1.00177 & 0.876194 & 55.85 & 35.77 & 20.39 & 31.59 & 2.77 & 0.48 \\
\hline 22-Apr-2009 & 116 & 66 & 78 & 0.99556 & 0.833224 & 45.77 & 26.22 & 12.34 & 21.93 & 1.77 & 0.22 \\
\hline 29-Sep-2009 & 116 & 66 & 142 & 1.01230 & 0.75088 & 37.24 & 21.45 & 10.48 & 17.11 & 1.39 & 0.17 \\
\hline
\end{tabular}

Sources: (1) Chander et al. (2009); (2) our image with calculations; (3) the DN of our image. DOY is the day of year.

Table 4. Values of $\tau_{0}(1), \mathrm{S}_{0}(2)$, and a(3) for every spectral Landsat band for both healthy and water-deficient rice

\begin{tabular}{|l|c|c|c|}
\hline \multicolumn{1}{|c|}{ Band } & $\tau_{0}$ & $\mathrm{~S}_{0}\left(\mathrm{Wm}^{-2} \mu \mathrm{m}^{-1}\right)$ & $\mathrm{a}$ \\
\hline ETM1 & 0.5 & 1997 & 0.7757 \\
\hline ETM2 & 0.3 & 1812 & 0.7957 \\
\hline ETM3 & 0.25 & 1533 & 0.6192 \\
\hline ETM4 & 0.20 & 1039 & 0.9655 \\
\hline ETM5 & 0.125 & 230.8 & 0.1257 \\
\hline ETM7 & 0.075 & 84.9 & 0.0437 \\
\hline
\end{tabular}

Sources: (1) Dozier (1989); (2) Chander et al. (2009); (3) our image with calculations. 
Table 5. Plant height at several rice ages

\begin{tabular}{|r|r|r|r|r|r|r|r|r|}
\hline \multirow{2}{*}{ Age } & & \multicolumn{7}{|c|}{ Rice age (cm) } \\
\cline { 2 - 9 } & I-1 & I-2 & II-1 & II-2 & III-1 & IV-1 & IV-2 & V-1 \\
\hline 28 & 40.91 & 42.22 & 43.51 & 40.18 & 58.72 & 53.65 & 49.74 & 80.46 \\
\hline 35 & 60.77 & 62.08 & 54.89 & 54.64 & 63.81 & 71.53 & 70.77 & 85.45 \\
\hline 42 & 77.55 & 78.79 & 65.63 & 67.55 & 68.76 & 86.67 & 88.28 & 90.01 \\
\hline 49 & 91.24 & 92.34 & 75.74 & 78.90 & 73.55 & 99.04 & 102.26 & 94.14 \\
\hline 56 & 101.85 & 102.73 & 85.21 & 88.70 & 78.20 & 108.67 & 112.71 & 97.84 \\
\hline 63 & 109.36 & 109.97 & 94.05 & 96.93 & 82.70 & 115.54 & 119.64 & 101.10 \\
\hline 70 & 113.79 & 114.06 & 102.25 & 103.61 & 90.01 & 119.66 & 123.04 & 103.94 \\
\hline 77 & 115.14 & 114.99 & 109.81 & 108.72 & 91.26 & 121.02 & 122.90 & 106.34 \\
\hline 84 & 113.39 & 112.76 & 116.73 & 112.28 & 95.32 & 119.63 & 119.24 & 108.32 \\
\hline 91 & 108.56 & 107.38 & 123.02 & 114.28 & 99.23 & 115.48 & 112.06 & 109.86 \\
\hline
\end{tabular}

Table 6. Greenness of rice leaves at several rice ages

\begin{tabular}{|r|r|r|r|r|r|r|r|r|}
\hline \multirow{2}{*}{ Age } & & \multicolumn{7}{|c|}{ Rice greenness (SPAD unit) } \\
\cline { 2 - 9 } & I-1 & I-2 & II-1 & II-2 & III-1 & IV-1 & IV-2 & V-1 \\
\hline 28 & 35.70 & 35.66 & 34.93 & 35.09 & 38.66 & 45.11 & 36.48 & 28.96 \\
\hline 35 & 38.22 & 36.62 & 36.83 & 36.69 & 38.00 & 43.13 & 37.81 & 32.86 \\
\hline 42 & 39.78 & 37.00 & 37.92 & 37.82 & 37.38 & 41.34 & 38.58 & 35.48 \\
\hline 49 & 40.38 & 36.79 & 38.22 & 38.47 & 36.83 & 39.75 & 38.77 & 36.82 \\
\hline 56 & 40.01 & 35.99 & 37.71 & 38.63 & 36.34 & 38.36 & 38.40 & 36.87 \\
\hline 63 & 38.69 & 34.60 & 36.39 & 38.32 & 34.00 & 37.16 & 37.46 & 35.64 \\
\hline 70 & 36.41 & 32.63 & 34.27 & 37.53 & 35.53 & 36.16 & 35.95 & 33.12 \\
\hline 77 & 33.16 & 30.06 & 31.35 & 36.25 & 35.21 & 35.35 & 33.87 & 29.32 \\
\hline 84 & 28.96 & 26.91 & 27.63 & 34.50 & 34.96 & 34.74 & 31.22 & 24.24 \\
\hline 91 & 23.79 & 23.17 & 23.10 & 32.26 & 34.76 & 34.33 & 28.01 & 17.87 \\
\hline
\end{tabular}

Table 7. Height times greenness of rice leaves at several rice ages

\begin{tabular}{|r|c|c|c|c|c|c|c|c|}
\hline \multirow{2}{*}{ Age } & \multicolumn{8}{|c|}{ Rice height $x$ Rice greenness } \\
\cline { 2 - 10 } & I-1 & I-2 & II-1 & II-2 & III-1 & IV-1 & IV-2 & V-1 \\
\hline 28 & 1460.53 & 1505.43 & 1519.59 & 1409.67 & 2270.52 & 2420.17 & 1814.41 & 2330.04 \\
\hline 35 & 2322.82 & 2273.57 & 2021.44 & 2005.09 & 2424.57 & 3085.21 & 2676.10 & 2808.12 \\
\hline 42 & 3084.89 & 2915.10 & 2489.13 & 2554.89 & 2570.38 & 3583.01 & 3405.56 & 3193.76 \\
\hline 49 & 3684.00 & 3396.97 & 2894.66 & 3035.21 & 2709.07 & 3937.24 & 3964.84 & 3466.01 \\
\hline 56 & 4075.16 & 3697.29 & 3213.09 & 3426.68 & 2841.73 & 4168.30 & 4328.04 & 3607.24 \\
\hline 63 & 4231.18 & 3805.27 & 3422.57 & 3714.40 & 2811.77 & 4293.37 & 4481.29 & 3603.13 \\
\hline 70 & 4142.67 & 3721.29 & 3504.32 & 3887.98 & 3198.15 & 4326.40 & 4422.74 & 3442.71 \\
\hline 77 & 3818.01 & 3456.84 & 3442.61 & 3941.52 & 3213.68 & 4278.09 & 4162.58 & 3118.29 \\
\hline 84 & 3283.38 & 3034.54 & 3224.80 & 3873.60 & 3332.10 & 4155.90 & 3723.03 & 2625.54 \\
\hline 91 & 2582.74 & 2488.16 & 2841.33 & 3687.29 & 3449.16 & 3964.06 & 3138.35 & 1963.44 \\
\hline
\end{tabular}

Table 8. Samples of Landsat image pixels of B3, B4, NDVI, and rice yield

\begin{tabular}{|c|c|r|r|}
\hline \multirow{2}{*}{ B3 } & \multirow{2}{*}{ B4 } & \multirow{2}{*}{ NDVI } & Rice yield \\
\cline { 4 - 4 } & & & Ton/ha \\
\hline 27.21 & 137.21 & 0.67 & 5.70 \\
\hline 27.11 & 138.01 & 0.71 & 6.51 \\
\hline 24.41 & 130.02 & 0.68 & 5.14 \\
\hline 28.17 & 136.81 & 0.69 & 6.37 \\
\hline 32.80 & 125.43 & 0.59 & 3.58 \\
\hline 26.54 & 142.90 & 0.73 & 6.91 \\
\hline 23.09 & 153.69 & 0.63 & 5.15 \\
\hline 27.83 & 154.11 & 0.69 & 5.50 \\
\hline 29.69 & 148.40 & 0.67 & 6.13 \\
\hline 34.33 & 168.07 & 0.73 & 7.65 \\
\hline 29.48 & 155.59 & 0.68 & 5.92 \\
\hline 30.25 & 158.85 & 0.74 & 7.49 \\
\hline 26.31 & 153.87 & 0.64 & 5.15 \\
\hline 27.88 & 162.98 & 0.71 & 6.16 \\
\hline
\end{tabular}


Table 9. Comparison between rice yield resulting from the estimation and the reference data

\begin{tabular}{|l|r|r|r|r|}
\hline \multirow{2}{*}{ B3 } & \multirow{2}{*}{ B4 } & \multirow{2}{*}{ NDVI } & \multicolumn{2}{|c|}{ Rice yield (ton/ha) } \\
\cline { 4 - 5 } & & & Reference & Estimation \\
\hline 25.97 & 148.55 & 0.70 & 7.23 & 6.35 \\
\hline 29.20 & 168.82 & 0.71 & 6.90 & 6.42 \\
\hline 26.84 & 159.11 & 0.71 & 7.03 & 6.59 \\
\hline 30.40 & 157.29 & 0.68 & 5.97 & 5.69 \\
\hline 31.16 & 146.86 & 0.65 & 5.34 & 5.10 \\
\hline 31.16 & 157.24 & 0.67 & 5.46 & 5.53 \\
\hline 28.96 & 163.27 & 0.70 & 6.70 & 6.25 \\
\hline 32.11 & 177.31 & 0.69 & 6.06 & 6.11 \\
\hline 28.12 & 165.23 & 0.71 & 6.74 & 6.53 \\
\hline 29.28 & 185.47 & 0.73 & 7.33 & 7.04 \\
\hline 30.11 & 188.69 & 0.72 & 7.18 & 6.96 \\
\hline 31.34 & 223.90 & 0.75 & 8.66 & 7.88 \\
\hline
\end{tabular}

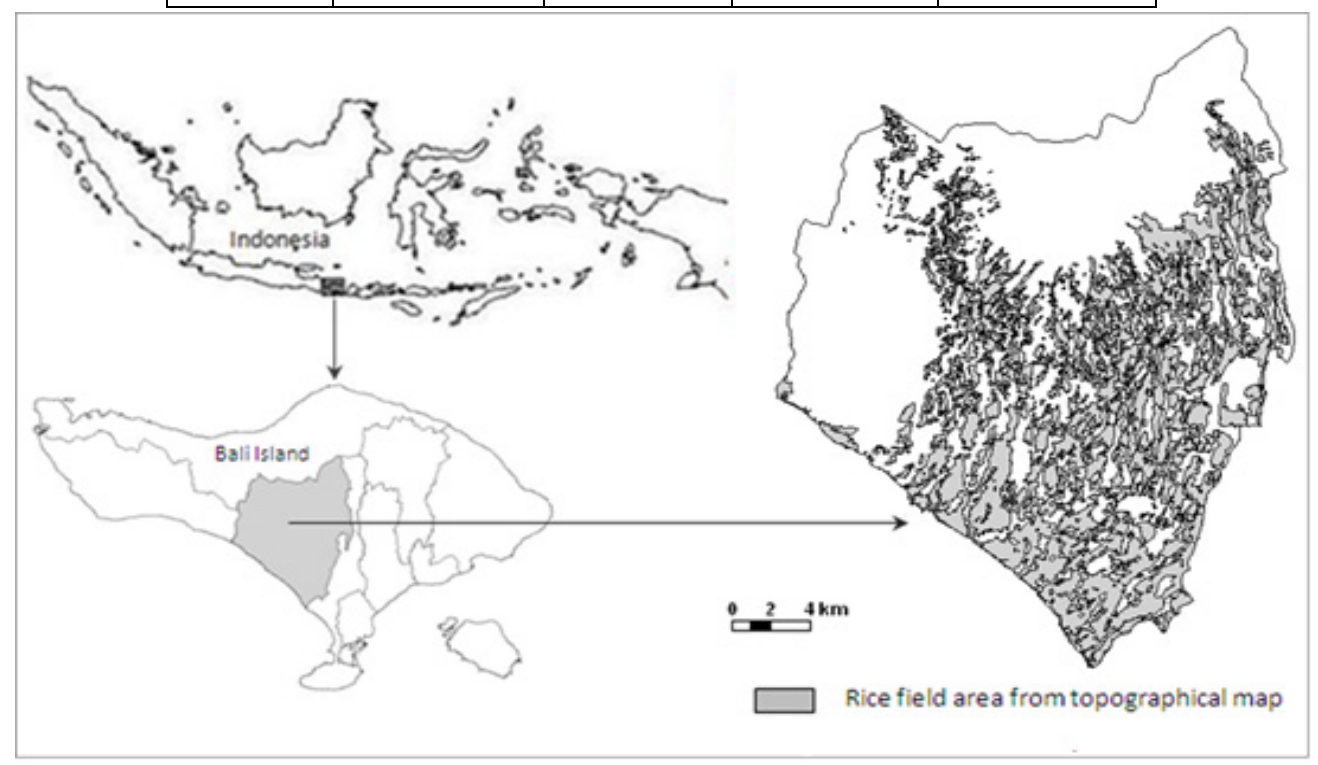

Figure 1. Location map of the study area

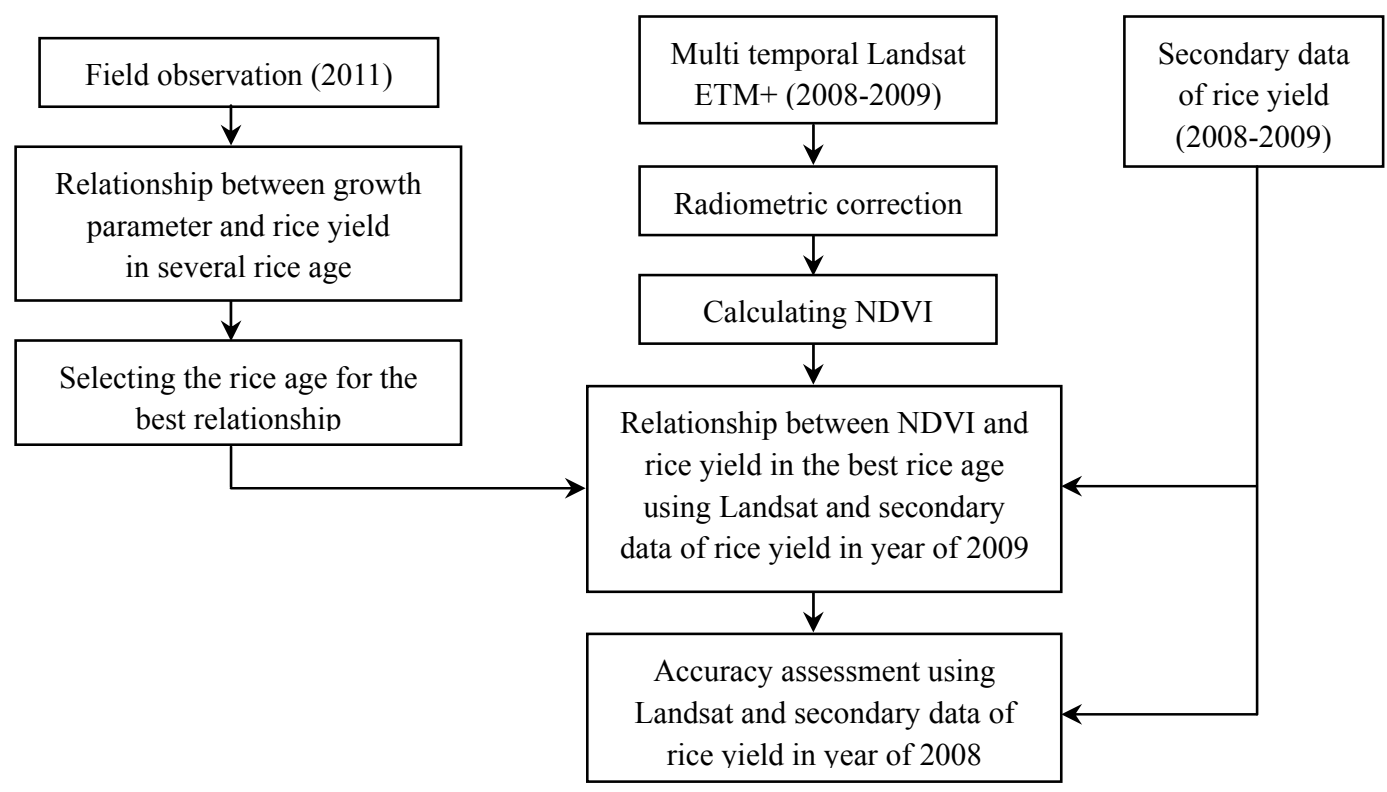

Figure 2. Research procedure used in this study 


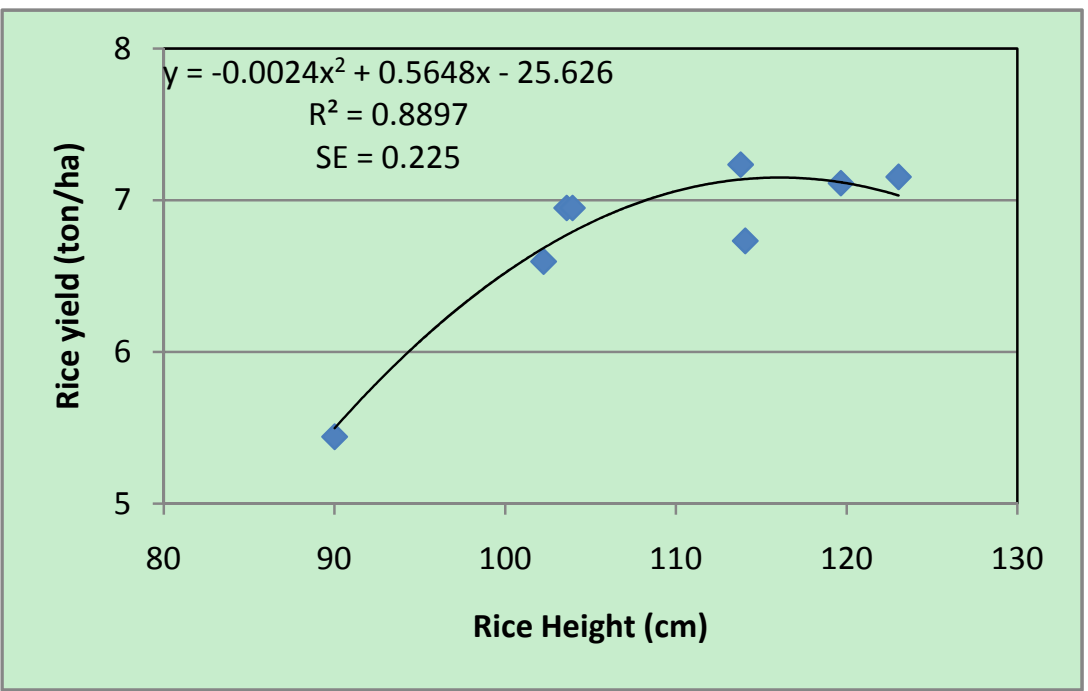

Figure 3. Relationship between rice height and rice yield at 63 days

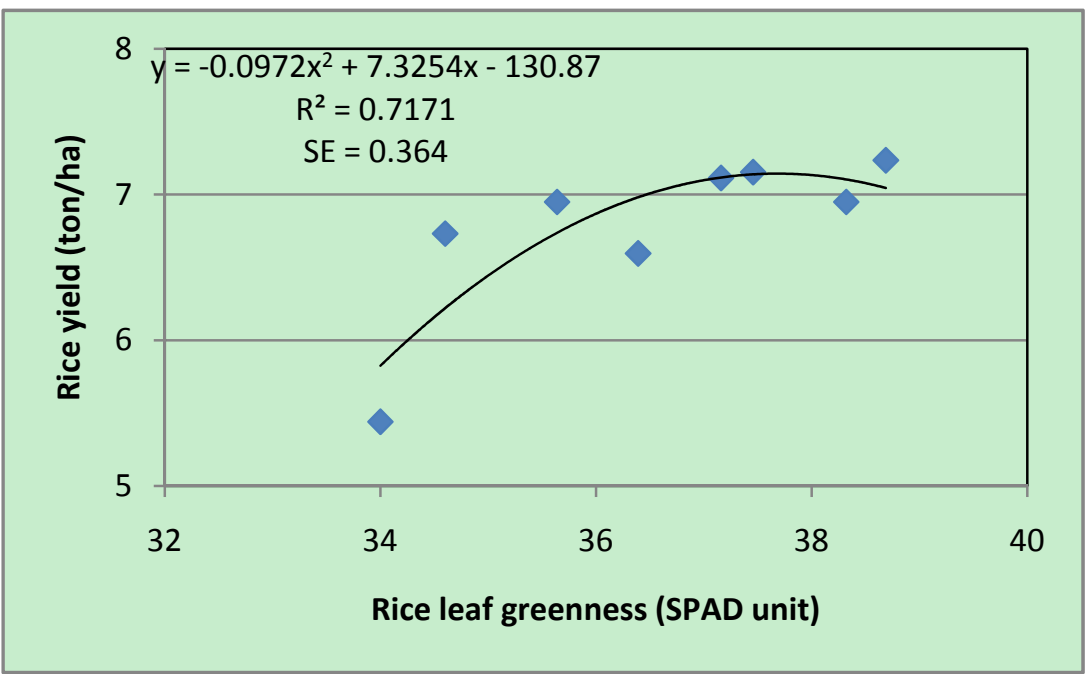

Figure 4. Relationship between rice leaf greenness and rice yield at 63 days

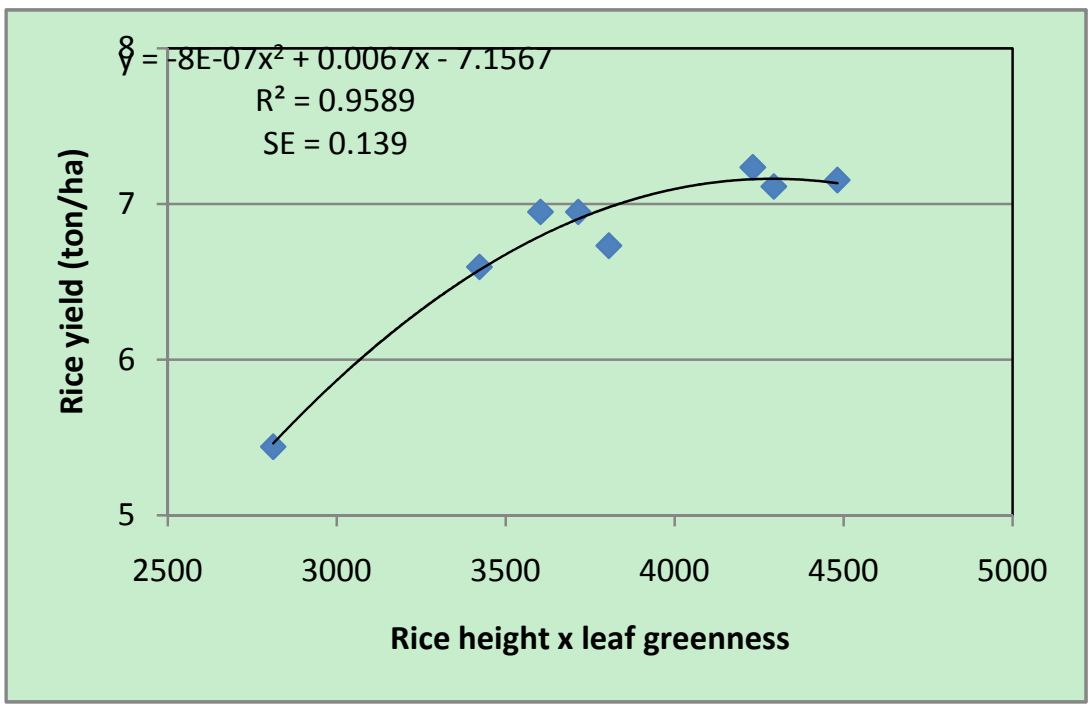

Figure 5. Relationship between rice height times rice leaf greenness and rice yield at 63 days 


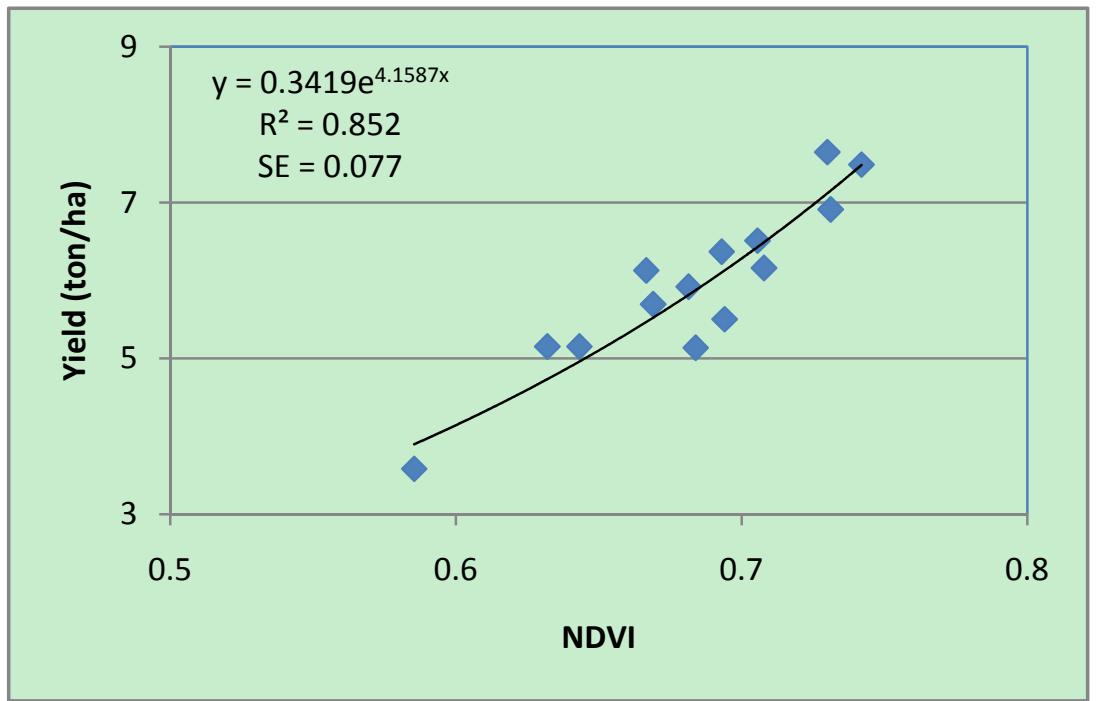

Figure 6. Relationship between NDVI and rice yield at 63 days

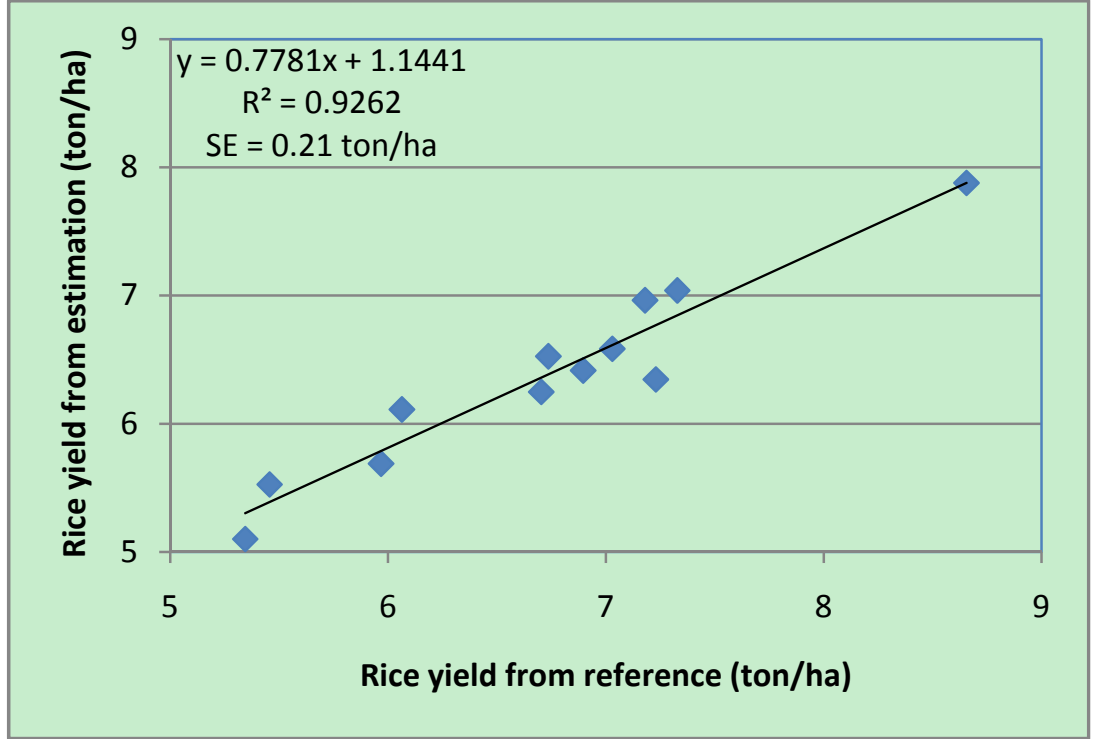

Figure 7. Relationship between rice yield resulting from the estimation and the reference data 